\title{
Quantitative Myasthenia Gravis Score: a Brazilian multicenter study for translation, cultural adaptation and validation
}

\author{
Teste Quantitativo para Miastenia Gravis: estudo multicêntrico brasileiro para tradução, \\ adaptação cultural e validação \\ Ezequiel Fernandes Oliveira ${ }^{1}$, Berenice Cataldo Oliveira Valério², Valéria Cavalcante ${ }^{3}$, Jessica Julioti Urbano', \\ Anderson Soares Silva', Melissa Nunes Polaro², Sergio Roberto Nacif4, Claudia Santos Oliveira', \\ Maria Bernadete Dutra Resende ${ }^{5}$, Acary Souza Bulle Oliveira ${ }^{3}$, Luis Vicente Franco Oliveira
}

\begin{abstract}
Objective: To perform the translation, cross-cultural adaptation and validation of the Quantitative Myasthenia Gravis Score (QMGS) to Brazilian Portuguese in accordance with international ethical standards. Methods: The following steps were taken: (1) implementation of the translation protocol and transcultural adaptation, (2) validation of the adapted content, and (3) assessment of reliability. To check intraand inter-observer reproducibility, each patient underwent two interviews with interviewer-A and one with B. The QMGS was compared to the Myasthenia Gravis Composite Scale and Myasthenia-specific Quality of Life Questionnaire. Results: Our study group consisted of 30 patients, with a mean age of $47.6 \pm 11.4$ years and a mean duration of illness of $11.33 \pm 8.49$ years. Correlation between the QMGS and MGC was very strong ( $r=0.928 ; p<0.001)$ and substantial between the QMGS and MG-QOL $15(r=0.737 ; p<0.001)$. Conclusion: The Brazilian Portuguese translation, and validation of the QMGS was successfully performed.
\end{abstract}

Keywords: myasthenia gravis; cross-cultural comparison; translations; validation studies.

\section{RESUMO}

Objetivo: O objetivo foi realizar a tradução e validação do teste quantitativo para Miastenia Gravis (QMGS) para Português do Brasil, de acordo com as diretrizes internacionais. Métodos: Foram realizadas as etapas de implementação do protocolo de tradução e adaptação transcultural, validação do conteúdo adaptado e avaliação da confiabilidade. Para verificar a reprodutibilidade intra e inter-observador cada paciente foi submetido a duas entrevistas por um entrevistador-A e um B. O QMGS foi comparado ao MG Composite Scale e Myasthenia-specific Quality of Life Questionnaire. Resultados: 0 estudo inclui 30 pacientes, com a média de idade de 47,6 $\pm 11,4$ anos e tempo médio de doença de $11,33 \pm 8,49$ anos. A correlação entre QMGS e MGC apresentou-se muito forte $(r=0,928 ; p<0,001)$ e substancial entre QMGS e MG-QOL 15 $(r=0,737 ; p<0,001)$. Conclusão: A tradução, e validação do QMGS para o português do Brasil foi realizada com sucesso.

Palavras-chave: miastenia gravis; comparação transcultural; traduções; estudos de validação.

Myasthenia gravis (MG) is a chronic autoimmune neuromuscular disorder characterized by weakness of the skeletal muscles ${ }^{1}$. In approximately $85 \%$ to $90 \%$ of patients with MG, antibodies against nicotinic acetylcholine receptors are identified in the neuromuscular junctions, with a smaller group of patients having autoantibodies against muscle-specific kinase $^{2}$, low-density lipoprotein-related protein 4, and even against agrin ${ }^{3,4}$.

\footnotetext{
${ }^{1}$ Universidade Nove de Julho, Programa de Pós-Graduação Doutorado em Ciências da Reabilitação, São Paulo SP, Brasil; ${ }^{2}$ Faculdade de Ciências Médicas da Santa Casa de São Paulo, Departamento de Clínica Médica, Disciplina de Neurologia, São Paulo SP, Brasil; ${ }^{3}$ Universidade Federal de São Paulo, Departamento de Neurologia e Neurocirurgia, Divisão de Distúrbios Neuromusculares, São Paulo SP, Brasil; ${ }^{4}$ Hospital Servidor Publico Estadual, Programa de Pós-Graduação Doutorado em Ciências da Saúde, São Paulo SP, Brasil; 5Universidade de São Paulo, Faculdade de Medicina, Hospital das Clínicas, Departamento de Neurologia Clínica, São Paulo SP, Brasil. Correspondence: Luis Vicente Franco Oliveira; Rua Itapirucu, 380 / apto 111; 05006-000 São Paulo SP, Brasil; E-mail: oliveira.lvf@pq.cnpq.br Conflict of interest: There is no conflict of interest to declare.

Support: The Sleep Laboratory receives funding from the Nove de Julho University (Brazil) and research projects approved by the Brazilian fostering agencies Fundação de Amparo a Pesquisa do Estado de São Paulo (local acronym FAPESP; protocol no. 2003/01810-4) and LVFO receives Research Productivity modality PQIB grants by Conselho Nacional de Desenvolvimento Científico e Tecnológico (local acronym CNPq; process no. 313053/2014-6). EFO receives grants of Fundação de Amparo a Pesquisa do Estado de São Paulo (local acronym FAPESP; protocol no. 2015/11738-6).
} 
The incidence and prevalence rates of MG vary greatly from country to country, making it difficult to generalize the data. Nonetheless, crude estimates are possible using the combination of pooled estimates and the range of observed frequencies. The incidence of all MG is: 5.3 per million person-years (C.I.: 4.41, 6.12), range: 1.7 - 21.3, and prevalence: 77.67 cases per million (C.I.: 63.98, 94.30), range: 15 - $179^{5}$.

The Myasthenia Gravis Foundation of America recommends that the Quantitative Myasthenia Gravis Score (QMGS) be used in all prospective clinical trials on $\mathrm{MG}^{6,7}$. The QMGS was developed by Besinger et al. in 1983 as a clinical scoring system to assess clinical outcomes in patients with $\mathrm{MG}^{8}$. The original scale comprised eight items, graded from 0 to 3 , where 3 is indicative of a higher severity of impairment. In 1987, Tindall et al. modified the scale, increasing the number of items from eight to 13 to improve the responsiveness of the scale in evaluating outcomes of treatment interventions for $\mathrm{MG}^{9,10}$.

In 1992, Tindall et al. ${ }^{10}$ used the modified QMGS to evaluate the effectiveness of a six-month treatment with cyclosporine (5 mg/kg per body weight) compared to a placebo group. Thirty-nine patients were randomized to the cyclosporine or the placebo group, with outcome measures evaluated monthly. Outcome measures included: the QMGS, anti-human acetylcholine receptor antibody titer, and dose of corticosteroid medication. At the six-month end-point, patients in the cyclosporine group exhibited significant increases in strength $(p=0.004)$ and reduction in antireceptor antibody titer $(\mathrm{p}=0.01)$, compared to those in the placebo group. Subsequently, the QMGS scale underwent further modification by Barohn et al. ${ }^{11}$

In its current format, the QMGS is a 13-item measurement tool used to quantify disease severity in patients with MG, including ocular, bulbar, respiratory, and limb function, with a total score range of 0 to 39 , where a higher score is indicative of greater disease severity. The reliability and longitudinal validity of the QMGS have been demonstrated in several studies ${ }^{12,13}$.

From a clinical perspective, the QMGS provides an easyto-use outcome measure that requires minimal equipment. Moreover, a change of 3.5 points in the total score is considered a clinically meaningful improvement for patients with MG. Therefore, the aim of this study was to perform the translation, cultural adaptation, and validation of the QMGS to extend its application in clinical practice and research with patients with MG in the Portuguese community of Brazil. According to our knowledge, this is the first translation and cultural adaptation of QMGS for another language.

\section{METHODS}

A search of the literature was performed to identify previous research on the adaptation and use of the QMGS for the Brazilian Portuguese population. The following databases were searched using the combination keywords "Quantitative Myasthenia Gravis Score and Portuguese validation": Medline, PubMed, Scientific Electronic Library Online, and Scientific and Technical Literature of Latin America and the Caribbean. No published information was identified.

Four neuromuscular disease research centers collaborated in our study. All methods and procedures were performed in accordance with the ethical standards established in the 1964 Declaration of Helsinki (as revised in Hong Kong in 1989 and Edinburgh, Scotland in 2000). Our study complied with the Regulatory Guidelines and Norms for Research Involving Human Subjects of the National Health Board of the Brazilian Health Ministry, issued in December 2012. Our study is part of a previously-published research proto$\mathrm{Col}^{14}$, approved by the Human Research Ethics Committee of Nove de Julho University (Brazil) under process no. 360.488 and registered with the World Health Organization under Universal Trial Number (UTN) U1111-1147-7853 and the Brazilian Registry of Clinical Trials (REBEC) RBR -7ckpdd.

Written informed consent was obtained prior to enrollment and participants were allowed to withdraw from the study, at any time, without consequence. Our eligibility criteria were as follows: a clinical diagnosis of MG according to the Myasthenia Gravis Foundation of America (MGFA) criteria; 18 to 75 years of age; both sexes; clinically stable patients; and capable of and willing to provide informed consent. Excluded from our study were patients with other neuromuscular, cardiovascular, and respiratory diseases, episodes of clinical decompensation of their disease in the two months prior to the study, a prior stroke, history of mental disease, or abuse of drugs and/or alcohol. We undertook the process of translation, cultural adaptation, and validation of the QMGS based on previously-published standardized rules ${ }^{15,16}$. A flowchart of the study is shown in Figure 1.

\section{First stage}

The original version of the QMGS was translated from English to Brazilian Portuguese by three bilingual translators, a physical therapist; a neurologist, and a certified professional translator, all of whom were blinded to the purpose of our study. The three translated versions were evaluated, compared, and merged into an initial Brazilian Portuguese draft version.

\section{Second stage}

Two native English-speaking translators, a certified professional translator, and a neurologist with no knowledge of the QMGS or of our research aim independently performed a back-translation of the final draft version from Brazilian-Portuguese to English. The back-translated English version was compared to the original English version with adjustments made to the Brazilian-Portuguese version to correct identified discrepancies. 


\section{FIRST STAGE}

First translation of the QMGS original version

3 bilingual translators

(physiotherapist, physician, sworn translator)

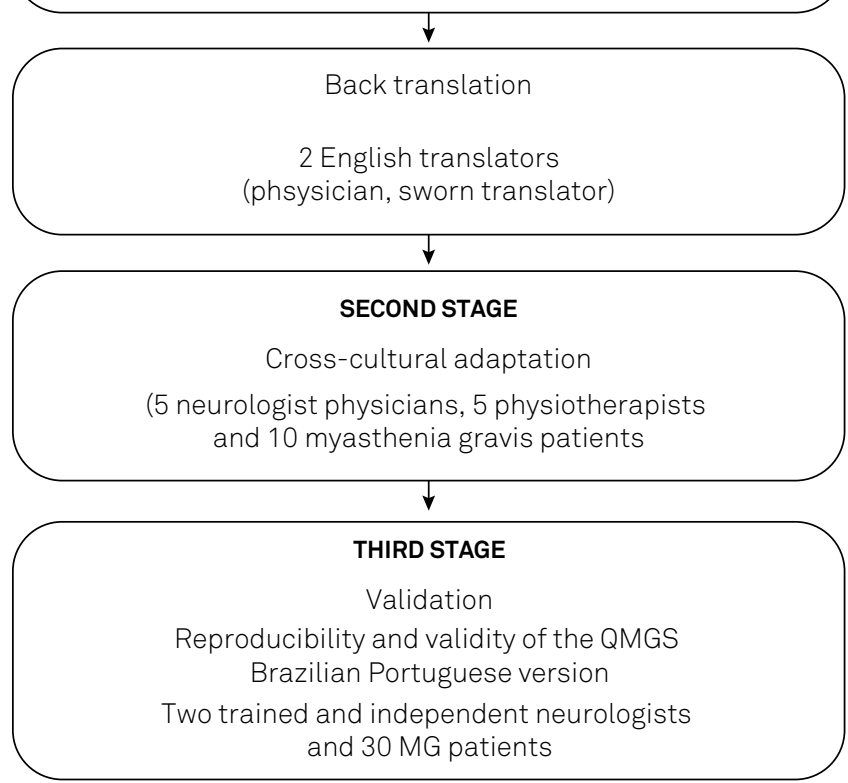

Figure 1. Flowchart of the study.

\section{Third stage}

A cultural adaptation of the Brazilian-Portuguese version of the QMGS, updated after the back-translation process, was subsequently undertaken, enrolling 10 patients with MG from the four neuromuscular disease research centers collaborating in our study. We added the phrase "difficult to understand" as a response option in the Brazilian-Portuguese version. Initially, we established an understanding of each item by $90 \%$ of healthcare professionals for the Brazilian-Portuguese translation to be acceptable, with the translation process to be repeated if this threshold was not achieved.

Five neurologists and five physiotherapists were recruited to verify the clarity of clinical terminology for the translated QMGS version. Again, a threshold of $\geq 90 \%$ was used for the translation to be deemed acceptable for clinical practice. In completing their review, the healthcare professionals also commented on the overall clarity of the QMGS. Ambiguous terms were discussed and replaced by alternative terms having semantic equivalence and appropriate to the Brazilian culture. A final version of the Brazilian Portuguese QMGS was consolidated without compromising the intended meaning of the original version (Figure 2).

\begin{tabular}{|c|c|c|c|c|c|}
\hline Comprometimento & Nenhum & Leve & Moderado & Grave & \\
\hline Graduação & 0 & 1 & 2 & 3 & 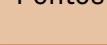 \\
\hline Visão dupla (olhar fixo lateral) (segundos) & 60 & $11-59$ & $1-10$ & Espontâneo & \\
\hline Ptose (olhar fixo para cima) (segundos) & 60 & $11-59$ & $1-10$ & Espontâneo & \\
\hline Músculos faciais & $\begin{array}{c}\text { Fechamento } \\
\text { normal das } \\
\text { pálpebras. }\end{array}$ & $\begin{array}{l}\text { Fechamento } \\
\text { completo. } \\
\text { Resistência } \\
\text { fraca. }\end{array}$ & $\begin{array}{l}\text { Fechamento } \\
\text { completo. } \\
\text { Sem resistência }\end{array}$ & $\begin{array}{l}\text { Fechamento } \\
\text { incompleto. }\end{array}$ & \\
\hline Deglutição (120 ml água) & Normal & $\begin{array}{l}\text { Tosse mínima ou } \\
\text { Limpar a garganta }\end{array}$ & $\begin{array}{c}\text { Tosse intensa, } \\
\text { engasga ou } \\
\text { regurgitação nasal }\end{array}$ & $\begin{array}{l}\text { Não consegue } \\
\text { engolir Teste não } \\
\text { realizado. }\end{array}$ & \\
\hline Contar em voz alta de 1 a 50. (início da disartria) & $\begin{array}{l}\text { Nenhum sinal } \\
\text { até } 50\end{array}$ & $\begin{array}{l}\text { Disartria } \\
\text { entre } 30-49\end{array}$ & $\begin{array}{l}\text { Disartria } \\
\text { entre 10-29 }\end{array}$ & $\begin{array}{l}\text { Disartria } \\
\text { até } 9\end{array}$ & \\
\hline Braço direito estendido ( $90^{\circ}$ sentado) (segundos) & 240 & $90-239$ & $10-89$ & $0-9$ & \\
\hline Braço esquerdo estendido ( $90^{\circ}$ sentado) (segundos) & 240 & $90-239$ & $10-89$ & $0-9$ & \\
\hline Capacidade Vital Forçada (\% do predito) & $\geq 80 \%$ & $65-79 \%$ & $50-64 \%$ & $<50 \%$ & \\
\hline \multicolumn{6}{|l|}{ Preensão palmar direita (kg) } \\
\hline Homem & $\geq 45$ & $15-44$ & $5-14$ & $0-4$ & \\
\hline Mulher & $\geq 30$ & $10-29$ & $5-9$ & $0-4$ & \\
\hline \multicolumn{6}{|l|}{ Preensão palmar esquerda (kg) } \\
\hline Homem & $\geq 35$ & $15-34$ & $5-14$ & $0-4$ & \\
\hline Mulher & $\geq 25$ & $10-24$ & $5-9$ & $0-4$ & \\
\hline $\begin{array}{l}\text { Em supino, manter a cabeça erguida em } 45 \text { graus. } \\
\text { (segundos) }\end{array}$ & 120 & $30-119$ & $1-29$ & 0 & \\
\hline $\begin{array}{l}\text { Perna direita estendida } 45 \text { a } 50^{\circ} \text { (supino) } \\
\text { (segundos) }\end{array}$ & 100 & $31-99$ & $1-30$ & 0 & \\
\hline $\begin{array}{l}\text { Perna esquerda estendida } 45 \text { a } 50^{\circ} \text { (supino) } \\
\text { (segundos) }\end{array}$ & 100 & $31-99$ & $1-30$ & 0 & \\
\hline
\end{tabular}

Figure 2. Quantitative tests for myasthenia gravis in Brazilian Portuguese. 
Reliability and validity of the QMGS Brazilian

Portuguese version

A sample of convenience of 30 patients, with a confirmed clinical diagnosis of MG based on the criteria of the MGFA and confirmed by the neurologists, was recruited to evaluate the reliability and validity of the Brazilian-Portuguese version of the QMGS. The 10 patients who participated in Phase III, cultural adaptation, were included in the validation component of our study.

Two trained neurologists (observer A and B) evaluated the QMGS at three time points. To assess inter-observer reliability, neurologists completed the QMGS, independently, within a two-hour interval. To assess intra-observer reliability, observer A completed the QMGS evaluation at one-week intervals, with interviews conducted at the same time of day.

The concurrent validity of the Brazilian Portuguese version of the QMGS was evaluated against the Portuguese version of the Myasthenia Gravis Composite Scale (MGC) ${ }^{17}$ and the Portuguese version of the 15-item Myasthenia-specific Quality of Life Questionnaire (MG-QOL 15) ${ }^{18}$ in a group of 30 patients with MG. The same evaluator applied the MGC and QMGS. The MGC is a 10-item scale designed to evaluate the function of patients with MG, with the response scale for each MGC items weighted in terms of the impact of the item on overall function. For example, ptosis scores 3 points, hip flexion weakness scores 5 points, and severity of respiratory symptoms for ventilator-dependent patients scores 9 points. The maximum possible score on the MGC is 50 points, with a higher score reflecting a more severe disease state. The validity and reliability of the MGC has been established, both in the United States and Europe, with a 3-point reduction in total score being indicative of a clinically meaningful improvement in the function of a patient with $\mathrm{MG}^{19,20}$.

The 15-item MG-QOL is an easy-to-use instrument that evaluates three dimensions of health-related quality of life. The 15 items are scored on a scale of 0 to 4 , with the score on each item summed to provide the total score. A clinically meaningful cutoff is not available for the MG-QOL. Therefore, the total score is interpreted along a continuum, with a higher score being indicative of a perception of an increasingly poorer quality of life. Both the MGC and MG-QOL are widely used to evaluate the physical, social, and psychological aspects of life of patients with MG and are used to derive an overall evaluation of the health-related quality of life in this clinical population ${ }^{18,21}$.

Lung function tests were performed on the day following the clinical evaluation, using the KoKo Sx 1000 system (nSpire Health Inc., Longmont, CO, USA), based on the guidelines of the Brazilian Society of Pneumology ${ }^{22}$. Peak forced expiratory volume (measured over a 1-s expiration) and forced vital capacity were used for analysis, regardless of the form of the curve (i.e., peak values were not necessarily obtained from the best expiratory curves).
Handgrip strength was assessed using the JAMAR hydraulic hand dynamometer device (Lafayette Instrument Company, Inc., Lafayette, IN, USA), which is widely used to provide a simple measure of hand strength in clinical populations with neuromuscular diseases. The JAMAR hand dynamometer is adjustable to the size of a patient's hand ${ }^{23}$. Handgrip strength was evaluated with patients in a sitting position, with the shoulder in $180^{\circ}$ of forward flexion and the elbow in full extension.

\section{Statistical analysis}

Prior to data analysis, normality of data distribution was evaluated using the Shapiro-Wilk test. For parametric data, including anthropometric and demographic measures, the mean and standard deviation values were calculated.

Intra- and inter-observer reliability was assessed using Pearson's correlation coefficient and the intra-class correlation coefficient with two-way mixed effects model where people effects are random and measures effects are fixed. The intra- and inter-observer reliability was also evaluated for each item of the QMGS using Cohen's kappa test, with the following interpretation of the kappa index: $<0$, no agreement; $0-0.20$, slight agreement; $0.21-0.40$, fair agreement; $0.41-0.60$, moderate agreement; $0.61-0.80$, substantial agreement; and $0.81-1$, excellent agreement.

Spearman's rank correlation coefficient was used to evaluate agreement between the score on the items of the QMGS and the MGC and MG-QOL. For all analyses, a p value $<0.01$ was considered significant. Statistical analysis was performed with StatView 5.0 (SAS Institute, Cary, N.C., USA), and SPSS software (version 23.0, SPSS Inc. Chicago, IL, USA).

\section{RESULTS}

\section{Demographic data}

Thirty-six patients (25 women), with a confirmed diagnosis of MG using the criteria of the MGFA, were identified from the four neuromuscular clinics involved in our study: the Neuromuscular Diseases Research department of the Universidade Federal de São Paulo; the Department of Neurology of the Faculty of Sciences, physicians from Santa Casa de São Paulo; the Department of Neurology of the Hospital do Servidor Público Estadual; and the Child Neurology Clinic of the Hospital das Clínicas, Faculdade de Medicina, Universidade de São Paulo. Six patients did not meet our eligibility criteria and, therefore, were not enrolled in our study.

The demographic, clinical data, and classification of disease severity for our final study groups are shown in Table 1. Of the 30 patients forming our study group, 24 were women, with a mean age of $47.6 \pm 11.4$ years (range, $32-74$ years), and a mean duration of illness of $11.33 \pm 8.49$ years. The distribution of MGFA classification was as follows: four patients, Class I; 17 patients, Class II; eight patients, Class III; no patients in Class IV or V. Among the patients in our study group, $96 \%$ 
were using cholinesterase inhibitors and $36 \%$ were using immunosuppressant drugs.

On average, the QMGS was completed in 32 minutes, with an additional 18 minutes required for assessment of forced vital capacity by spirometry and eight minutes for hand grip strength. The kappa index of inter- and intra-observer reliability for each item of the QMGS is reported in Table 2, with all kappa values $\geq 0.81$, indicative of an excellent reliability for all items. Overall inter- and intra-observer reliability was confirmed by the intra-class correlation coefficient

Table 1. Baseline clinical and demographic variables.

\begin{tabular}{|c|c|c|}
\hline Variables & Patients $(n=30)$ & (\%) \\
\hline Female/Male & $24 / 6$ & - \\
\hline Age (years) & $47.6 \pm 11.4$ & - \\
\hline Body Mass Index & $27.5 \pm 5.4$ & - \\
\hline \multicolumn{3}{|l|}{ MGFA } \\
\hline 1 & 2 & 6.6 \\
\hline$\| A$ & 17 & 56.6 \\
\hline$\| \mathrm{B}$ & 2 & 6.6 \\
\hline IIIA & 5 & 16.6 \\
\hline IIIB & 4 & 13.3 \\
\hline QMGS & $11.4 \pm 5.7$ & - \\
\hline MGC & $12.93 \pm 7$ & - \\
\hline MG QOL - 15 score & $21.6 \pm 12$ & - \\
\hline
\end{tabular}

Table 2. Assessment of intra- and inter-interviewer reproducibility of Quantitative Myasthenia Gravis score (QMGS) with Cohen's kappa.

\begin{tabular}{lcc}
\hline QMGS items & Intra-interviewer & Inter-interviewer \\
\hline Double vision & 0.896 & 0.897 \\
Ptosis & 0.890 & 0.721 \\
Facial muscles & 0.947 & 0.893 \\
Swallowing & 0.710 & 0.815 \\
Speech following counting & 1.000 & 0.930 \\
aloud from 1-50 & 0.862 & 0.761 \\
Right arm outstretched & 0.841 & 0.792 \\
Left arm outstretched & 1.000 & 0.762 \\
Forced vital capacity & 1.000 & 0.826 \\
Right hand grip & 0.939 & 0.876 \\
Left hand grip & 0.772 & 0.854 \\
Head lifted & 0.875 & 0.875 \\
Right leg outstretched & 0.890 & 0.890 \\
Left leg outstretched & & \\
\hline
\end{tabular}

and Pearson's correlation coefficient reported in Table 3. Correlation between the QMGS and MGC was very strong $(\mathrm{R}=0.928 ; \mathrm{p}<0.001)$ and substantial between the QMGS and MG-QOL15 ( $\mathrm{R}=0.737 ; \mathrm{p}<0.001)$ as shown in Figure 3.

\section{DISCUSSION}

The use of common assessment tools is advocated by the Task Force of the Medical Scientific Advisory Council,
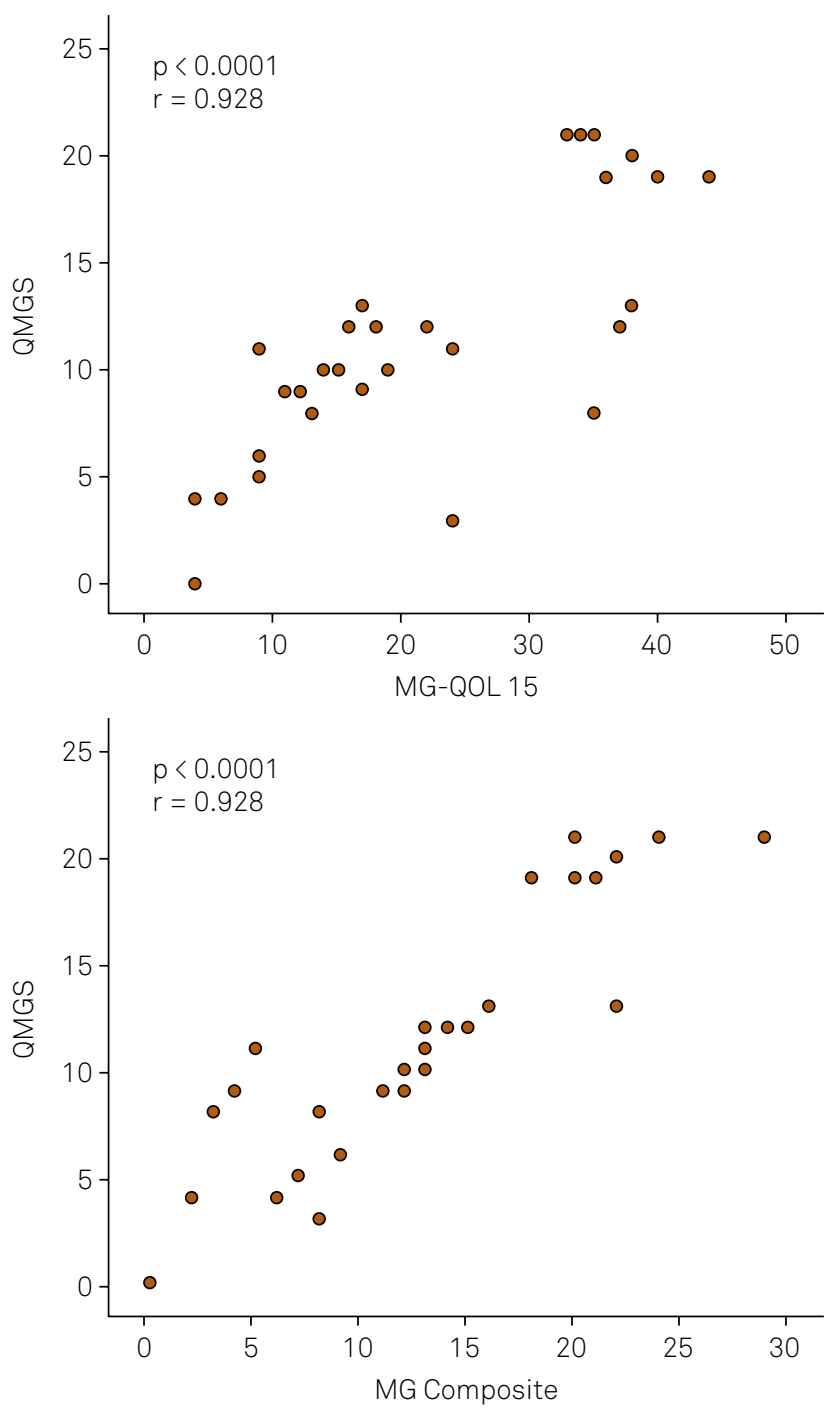

Figure 3. Correlation between the QMGS and MGC and between the QMGS and MG-QOL15.

Table 3. Analysis of the reproducibility by means of the Pearson's correlation coefficient and of the intra-class correlation coefficient values for the total score.

\begin{tabular}{|c|c|c|c|c|c|}
\hline Coefficient & Intra-interviewer & Inter-interviewer & mean \pm SD QMGS-A & mean \pm SD QMGS-B & mean \pm SD QMGS-A2 \\
\hline Pearson's & $0.998 *$ & $0.991 *$ & \multirow{2}{*}{$11.43 \pm 5.7$} & \multirow{2}{*}{$11.50 \pm 5.2$} & \multirow{2}{*}{$11.37 \pm 5.6$} \\
\hline Intra-class & $0.999 * *$ & $0.994^{\star * \star}$ & & & \\
\hline
\end{tabular}


with the MGFA proposing a series of classification systems and definitions of response to therapy for $\mathrm{MG}$ patients ${ }^{7}$, to achieve greater uniformity in the recording and reporting of clinical trials for MG. The QMGS is among the recommended assessment tools. However, to be applicable to different ethnic groups, patient-report assessments, such as the QMGS, require translation and validation for each population. A rigorous process of translation and cultural adaptation is required to ensure congruity with the original version of the measurement tool, facilitate uptake of the translated version, and eliminate the risk of systematic bias of results. For these reasons, we performed the translation and cultural adaption of the original English version of the QMGS for use with patients with MG of Portuguese ethnicity in Brazil according to published international standards ${ }^{15,16}$.

The excellent intra- and inter-observer reliability and clinically acceptable concurrent validity of the QMGS that we report in our study are comparable to values previously reported. Sharshar et al. ${ }^{12}$ evaluated the inter-observer reliability and concurrent validity of the QMGS against the Myasthenia Muscle Score. Among a group of 22 patients with $\mathrm{MG}$, including 13 men and nine women, with a mean age of 63 years (range, 25 to 80 years), they reported high inter-observer agreement and a high correlation in score between the QMGS and Myasthenia Muscle Score. Therefore, we propose that our translated version of the QMGS has the reliability required for its use in clinical trials and in practice.

The longitudinal construct validity of the QMGS was confirmed by Bedlack et al. in a prospective study with 53 patients with $\mathrm{MG}^{13}$. In this study, the authors demonstrated the correlation between the QMGS and manual muscle testing, as well as providing evidence of the responsiveness of the QMGS to differentiate change in disease severity between two visits as: unchanged, improved, or worse.

In our study, we found a very strong correlation between the QMGS and the MGC, as well as between the QMGS and the 15-item MG-QOL. Our results are comparable to those reported by Barnett et al. ${ }^{24}$ who observed a good association between the 15-item MG-QOL and the QMGS. We also confirmed the concordance between the QMGS and the MGFA classification of disease severity, Class I to III. It is important to acknowledge that our study group did not include patients in the MGFA Class IV and V. Barnett et al. ${ }^{25}$ similarly confirmed the sensitivity of the QMGS to differentiate disease severity among patients with MG, as well as to quantify treatment effectiveness. In particular, Barnett et al. provided evidence of the discriminative value of the timed items of the QMGS, evaluating upper and lower limb function and neck endurance.

In the process of validating the Brazilian Portuguese version of the QMGS, patients in our study group reported excellent understanding and applicability of the QMGS, with health professionals confirming the clinical applicability of the translated QMGS. Moreover, reliability measures (inter- and intra-observer reliability) for the translated QMGS were excellent, meeting the international standards for the clinical and research use of a translated and culturally-adapted measurement tool.

In conclusion, based on our results, we can affirm that the Brazilian Portuguese translation, cultural adaptation, and validation of the QMGS was successfully performed. We believe that the use of our Brazilian Portuguese version of the QMGS will improve care of patients with MG, including more precise monitoring of the clinical rehabilitation process, as well as a more effective comparison of clinical status.

\section{References}

1. Meriggioli MN, Sanders DB. Autoimmune myasthenia gravis: emerging clinical and biological heterogeneity. Lancet Neurol. 2009;8(5):475-90. https://doi.org/10.1016/S1474-4422(09)70063-8

2. Hoch W, McConville J, Helms S, Newsom-Davis J, Melms A, Vicent A. Auto-antibodies to the receptor tyrosine kinase MuSK in patients with myasthenia gravis without acetylcholine receptor antibodies. Nat Med. 2001;7(3):365-8. https://doi.org/10.1038/85520

3. Higuchi O, Hamuro J, Motomura M, Yamanashi Y. Autoantibodies to low-density lipoprotein receptor-related protein 4 in myasthenia gravis. Ann Neurol. 2011;69(2):418-22. https://doi.org/10.1002/ana.22312

4. Zhang B, Shen C, Bealmear B, Ragheb S, Xiong WC, Lewis RA. Autoantibodies to agrin in myasthenia gravis patients. PLoS One. 2014;9(3):e91816. https://doi.org/10.1371/journal.pone.0091816

5. Carr AS, Cardwell CR, McCarron PO, McConville J. A systematic review of population based epidemiological studies in Myasthenia Gravis. BMC Neurol 2010;10(1):46. https://doi.org/10.1186/1471-2377-10-46

6. Jaretzki A 3rd, Barohn RJ, Ernstoff RM, Kaminski HJ, Keesey JC, Penn AS et al. Myasthenia gravis: recommendations for clinical research standards. Neurology. 2000;55(1):16-23. https://doi.org/10.1212/WNL.55.1.16
7. Benatar M, Sanders DB, Burns TM, Cutter GR, Guptill JT, Baggi F et al. Recommendations for Myasthenia Gravis Clinical Trials. Muscle Nerve. 2012;45(6);6:909-17. https://doi.org/10.1002/mus.23330

8. Besinger UA, Toyka KV, Hömberg M, Heininger K, Hohlfeld R, Fateh-Moghadam A Myasthenia gravis: long-term correlation of binding and bungarotoxin blocking antibodies against acetylcholine receptors with changes in disease severity. Neurology. 1983;33(10):1316-21. https://doi.org/10.1212/WNL.33.10.1316

9. Tindall RS, Rollins JA, Phillips JT, Greenlee RG, Wells L, Belendiuk G. Preliminary results of a doubleblind, randomized, placebo-controlled trial of cyclosporine in myasthenia gravis. N Engl J Med. 1987;316(12):719-24. https://doi.org/10.1056/NEJM198703193161205

10. Tindall RS, Phillips JT, Rollins JA, Wells L, Hall K. A clinical therapeutic trial of cyclosporine in myasthenia gravis. Ann N Y Acad Sci. 1993;681 Myasthenia Gr:539-51. https://doi.org/10.1111/j.1749-6632.1993.tb22937.x

11. Barohn RJ, Mclntire D, Herbelin L, Wolfe GI, Nations S, Bryan WW. Reliability testing of the quantitative myasthenia gravis score. Ann NY Acad Sci. 1998;13(841):769-2. https://doi.org/10.1111/j.1749-6632.1998.tb11015.x 
12. Sharshar T, Chevret S, Mazighi M, Chillet P, Huberfeld G, Berreotta $C$ et al. Validity and reliability of two muscle strength scores commonly used as endpoints in assessing treatment of myasthenia gravis. J Neurol. 2000;247(4):286-90. https://doi.org/10.1007/s004150050585

13. Bedlack RS, Simel DL, Bosworth H, Samsa G,

Tucker-Lipscomb B, Sanders DB. Quantitative myasthenia gravis score: assessment of responsiveness and longitudinal validity. Neurology. 2005;64(11):1968-70. https://doi.org/10.1212/01.WNL.0000163988.28892.79

14. Oliveira EF, Urbano JJ, Santos IR, et al. Brazilian translation, crosscultural adaptation and validation of the MG composite scale and quantitative myasthenia gravis testing form: a multicentric study protocol. Man Ther Posturology Rehabil J. 2016;14:1-5. https://doi.org/10.17784/mtprehabjournal.2016.14.342

15. Guillemin F, Bombardier C, Beaton D. Cross-cultural adaptation of health-related quality of life measures: literature review and proposed guidelines. J Clin Epidemiol.1993;46 (12):1417-32. https://doi.org/10.1016/0895-4356(93)90142-N

16. Guillemin F. Cross-cultural adaptation and validation of health status measures. Scand J Rheumatol. 1995;24(2):61-3. https://doi.org/10.3109/03009749509099285

17. Oliveira EF, Lima VC, Perez EA, Polaro MN, Valério BC, Pereiro JR et al. Brazilian-Portuguese translation, cross-cultural adaptation and validation of myasthenia gravis composite scale: a multicentric study. Arq Neuropsiquiatr. 2016;74(11):914-20. https://doi.org/10.1590/0004-282×20160129
18. Mourão AM, Araújo CM, Barbosa LSM, Gomez RS, Burns TM, Lemos SMA et al. Brazilian cross-cultural translation and adaptation of the'Questionnaire of Life Quality Specific for Myasthenia Gravis - 15 items'. Arq Neuropsiquiatr. 2013;71(12):955-8. https://doi.org/10.1590/0004-282X20130180

19. Sadjadi R, Conaway M, Cutter G, Sanders DB, Burns TM. Psychometric evaluation of the myasthenia gravis composite using Rasch analysis. Muscle Nerve. 2012;45(6):820-5. https://doi.org/10.1002/mus.23260

20. Burns TM, Conaway MR, Cutter GR, Sanders DB. Construction of an efficient evaluative instrument for Myasthenia gravis: the MG composite. Muscle Nerve. 2008;38(6):1553-62. https://doi.org/10.1002/mus.21185

21. Burns TM, Grouse CK, Conaway MR, Sanders DB. Construct and concurrent validation of the MG-QOL15 in the practice setting. Muscle Nerve. 2010;41(2):219-26. https://doi.org/10.1002/mus.21609

22. Pereira CAC. Diretrizes para testes de função pulmonar. J Pneumol. 2002;28(supl 3):S1-82.

23. Figueiredo IM, Sampaio RF, Mancini MC, Silva FCM, Souza MAP. Test of grip strength using the Jamar dynamometer. Acta Fisiatr. 2007;14(2):104-10. https://doi.org/10.5935/0104-7795.20070002

24. Barnett $\mathrm{C}$, Katzberg H, Nabavi M, Bril V. The quantitative myasthenia gravis score: comparison with clinical, electrophysiological, and laboratory markers. J Clin Neuromuscul Dis. 2012;13(4):201-5. https://doi.org/10.1097/CND.0b013e31824619d5

25. Barnett TC, Bril V, Davis AM. Performance of individual items of the quantitative myasthenia gravis score. Neuromuscul Disord. 2013;23(5):413-7. https://doi.org/10.1016/j.nmd.2013.02.008 